injuries has not appeared, and, although strict liability for product injury has been taken up by the $\mathrm{EEC}^{2}$ the new law and the debate are both lost in the timeless committees of Brussels. Last year The Times pointed out that our present system of compensating for personal injury is "capricious, haphazard, and inconsistent" and said that the issues "should be argued out in public debate." 3 It went on to regret that no such debate was taking place, and censured this Government and the last for shelving the Pearson Report and the problem of compensation.

Few people would argue that the present British system is acceptable. It is very similar to the one that existed in New Zealand before 1974 (24 April, p 1243), and which was criticised by Justice Woodhouse's royal commission of 1967 as a fragmented response to a social problem that "cried out for co-ordinated and comprehensive treatment." 4 Too many injured people went uncompensated, the commission said; the common law system was inefficient, slow, and unrealistically difficult for many of the injured; and rehabilitation was hindered by the prolonged, adversarial system. Most of these criticisms would apply to the current British system.

So how can matters be improved? One radical option would be to sweep away the common law system and replace it with a no-fault scheme, and that is what has happened in New Zealand. When representatives of the Pearson Commission visited New Zealand they suggested that Britain should adopt such a system for compensating road injuries, but dismissed it-mainly on economic grounds-for other kinds of injury. The Government then ignored even the Pearson proposals for traffic injuries, but we believe that it should think again.

A no-fault system can be just, fast, and effective, as the New Zealand experience shows. Indeed, like the Australians before them, the New Zealanders have considered introducing an extended system whereby incapacitated people are compensated by need rather than cause (1 May, p 1323); thus a person severely incapacitated by disease would receive more compensation than a person more mildly incapacitated after being knocked down by a negligent driver. Humane logic leads inevitably to such a system, and need not be prohibitively expensive. Costing compensation schemes is difficult, ${ }^{5}$ but the greater efficiency of a no-fault scheme compared with a full legal system allows more people to be compensated for the same total expenditure.

Yet here in Britain the pressure of public opinion is pushing us towards more legal participation rather than less. Consumer groups continue to press for strict liability for product injury. We understand the concern that drives them on, but they would be much wiser to push for a no-fault system. Many of the American States have strict liability for product injury, and last year we published three articles describing the unhappy chaos that prevails in the United States. ${ }^{6-8}$

Here in Britain we need a comprehensive system for responding to incapacity. Compensation is only one response: prevention and rehabilitation are two much better ones. The Accident Compensation Corporation in New Zealand has responsibilities in all three responses. An examination of both the successes and the failures of the New Zealand systems suggests that Britain could obtain the best system in the world. To do so it should have a system of compensation for all incapacity from whatever cause overseen by an organisation that also had a wholehearted commitment to prevention and rehabilitation.

${ }^{1}$ Royal Commission on Civil Liability and Compensation for Personal Injury. Report. London: HMSO, 1978. (Cmnd 7054.) (Pearson Commission.)
${ }^{2}$ Anonymous. Compensation for drug injury. Br Med $\mathcal{f} 1979$;ii:1674-5.

${ }^{3}$ Anonymous. A neglected reform. The Times 1981 Aug $21: 13$ (col 1-3).

4 Royal Commission of Inquiry. Compensation for personal injury in New Zealand. Wellington: New Zealand Government, 1969.

${ }^{5}$ Palmer G. Compensation for incapacity: a study of law and social change in New Zealand and Australia. Wellington: Oxford University Press, 1979.

${ }^{6}$ Smith R. Problems both sides of the Atlantic. Br Med $\mathcal{F} 1981$;282:1443-5.

${ }^{7}$ Smith R. Product liability all dressed up American style. $\mathrm{Br} \mathrm{Med} \mathcal{F} 1981$; 282:1535-7.

${ }^{8}$ Smith R. Two solutions to an insoluble problem. Br Med $\mathcal{F} 1981$;282: 1610-2.

\section{How valuable is the Review Body?}

Most NHS doctors will be less than satisfied that for the second year running the Government has interfered with the Review Body's recommendations on their remuneration ( $p$ 1487). The country's international crisis and the consequent political uncertainty, its persisting economic and social diffculties, and the fact that NHS staff-many earning much less than doctors-are taking industrial action to improve a management offer of $4 \%$ will all doubtless influence the profession's medicopolitical response to the cut in the proposed increase from $9 \%$ to $6 \%$. Dissatisfaction is unlikely to be translated into militancy.

Short term a continuing 3\% loss may not seem worth making a fuss about; the long-term consequences, however, cannot be lightly dismissed. Taken with some pointers in the Twelfth Report, the 1981 and 1982 cuts will erode the real value of incomes and there could soon be a Health Service staffed with doctors whose commitment falls steadily from its present surprisingly high level. The manner in which the Government has cut the award this year will not improve doctors' confidence about their pay review system. Paying the global sum of $£ 90 \mathrm{~m}$ recommended by the Review Body but declining to reinstate last year's 3\% abatement as implicitly proposed in the report-an exercise facilitated by the way the Review Body presented its global recommendations-may be seen as deft political presentation by Whitehall: to doctors who recall the Prime Minister's promise about the Review Body's independence ${ }^{1}$ it smacks of sharp practice that will provoke widespread cynicism about such promises.

In the circumstances the statement by Sir Robert Clark, the Review Body's chairman, was remarkably mild (p 1487). No doubt the BMA's leaders may hear some franker views when they meet members of the Review Body-probably soon after the $B M \mathcal{F}$ has gone to press-to discuss their reactions to the Government's decision.

Meanwhile, Government cuts and percentages aside (and the estimated changes in the profession's remuneration from 1 April 1982 are given in the Supplement at pages 1487 to 1492 , there are some pertinent questions for doctors to ask. Firstly, do these annual reviews have any value other than a means of settling the remuneration of the two professions in a reasonably objective way without regular confrontations with the Government? Secondly, does this latest report show any shift in the Review Body's philosophy on doctors' and dentists' pay? Finally what is the future of this 20 -year-old review machinery ?2

The $B M \mathcal{F}$ believes that the answer to the first question is yes, for the following reasons. As well as receiving written evidence, mainly from the BMA's Joint Evidence Committee (p 1493) and the Health Departments, the Review Body 
also invites representatives of the two "sides" to attend and discuss that evidence. This probing by a group of experienced and knowledgeable outsiders means that doctors and civil servants alike have to prepare a logical case, backed up with carefully marshalled facts and figures, and be prepared to defend it. Rhetoric or militancy has no place in such a forum, though anecdotal professional experience can clearly reinforce a soundly argued case. Using the Office of Manpower Economics, which services all the review bodies, Sir Robert and his colleagues can initiate extensive inquiries of their own, whose results can be of value beyond the immediate arena of pay and the year under review. For example, this year the Review Body has surveyed junior doctors' work and responsibilities ( $p$ 1489), and taken a close look at GPs' deputising arrangements ( $p$ 1491). Would such extensive information necessarily be a by-product of annual confrontations on pay between the BMA and the Health Departments? A final point on the value of an independent and publically available review is that even if the Government of the day modifies the outcome an authoritative marker has been established on what doctors' incomes should be.

To turn to the second question, the contents of the latest report, the Review Body has signalled a continuing strategic change of direction in its assessment of the two professions' remuneration. ${ }^{2 a}$ In frankly admitting that a comparison with similar occupations its $9 \%$ recommendation of last year ${ }^{3}$ (cut to $6 \%$ by the Government $t^{4}$ " "left an average shortfall of rather less than $6 \%$," the Review Body reminds readers that it did not think it appropriate "to give external remuneration comparisons the same degree of emphasis it had done for the 1978-80 updating process." Doctors, whose work load and productivity are, as the report concedes, notoriously uncertain measurements for assessing reward, will be worried at the erosion of such a readily identifiable landmark. If the profession's income falls significantly in real terms doctors are bound to look to it as a future reference point for assessing the worth of a vocation most of whose practitioners are vulnerable to a monopoly state employer, a monopoly that may well be tightened if there is a change of government ( $p$ 1486).

In their Twelfth Report Sir Robert Clark and his fellow members also seem to be edging towards the Tory party's market-place economics when they emphasise the high quality and ample quantity of potential recruits to medicine. Furthermore, they point to the security of employment in NHS medicine compared with the increasing uncertainties of private sector occupations. Since these factors will probably not change quickly they could influence decisions on the appropriate levels of doctors' incomes in future.

On employment junior doctors may be disappointed at the Review Body's disbelief "that there has been any decline in the long-term employment prospects of those entering the hospital service," though they should welcome its confidence in the prospects offered by the Government's policy of increasing the number of consultant posts. They will also welcome the evidence of the Office of Manpower Economics survey proving the long hours that some juniors work-though, like employment prospects, patterns vary greatly among specialtiesfindings which have prompted the Review Body to award relatively higher increases to junior doctors, particularly registrars and SHOs (relativities which the Government has not disturbed). The juniors' arguments for very substantial rises in the values of units of medical time, with punitive levels where doctors work more than 80 hours a week (and the survey shows an unacceptable $10 \%$ of junior staff working and $44 \%$ on duty for longer than this time), did not find favour, because the Review Body, though critical of long hours, was not convinced that remuneration changes are a satisfactory remedy. This adds urgency to the search by the profession and the DHSS for a solution to unacceptably long working hours.

As well as its thorough study of juniors' work the Review Body examined deputising services and out-of-hours workas promised last year. General practitioners and deputising services will be relieved that nothing detrimental was uncovered and no restrictive proposals made. A warning signal has, however, been sounded in the comment: "We take the view that the evidence on the use of commercial deputising services points to a gradual but significant reduction in the amount of out-of-hours work undertaken, and on the disruption suffered personally, by general medical practitioners." On GPs' work load the report refers to "some indication of a moderation of work carried out-particularly in terms of out-of-hours work, and a general improvement in practice organisation." A recent informal BMA questionnaire to a sample of GPs suggests, however, that they do not feel that the demands on them have lessened. This illustrates the difficulties inherent in assessing work load. Not surprisingly consultants, too, are convinced that they work harder ( $p$ 1494) than the statistics produced by the Review Body suggest. Undoubtedly, one doctor's overloaded day is another's routine working hours and convincing criteria for measuring work load are still some way off. Even so, the subject will not vanish from future reviews. With outside pay comparisons further demoted, quality recruits abounding, and the NHS offering reasonably secure employment, the BMA might see it as worth while to commission a comprehensive study to formulate acceptable quantitative and qualitative assessments of doctors' work load.

What of the final question, on the Review Body's future? With abundant evidence in recent years of acrimonious andapart from key groups with industrial muscle like the minersdubiously productive pay negotiations in the public sector an independent review system still has something to offer. The nurses, particularly the Royal College of Nursing, see the promise of independent review machinery for them as an advance on their thoroughly unsatisfactory Whitley negotiating framework. Neither doctors, dentists, nor nurses are likely to support effective industrial action in pursuit of pay claims, so an independent umpire remains a sensible proposition, particularly as doctors' bargaining power is rather less powerful than it was in the 'sixties ${ }^{6}$ and 'seventies. ${ }^{7}$ The next two or three years in the NHS - and who dare look further ahead than that ?-are bound to be unsettled. At least a continuing Review Body will lessen the likelihood of disruptive clashes on pay between doctors and governments.

${ }^{1}$ Anonymous. BMA meets Secretary of State on pay. Br Med $\mathcal{f} 1981 ; 282$ 1988.

2 Royal Commission on Doctors' and Dentists' Remuneration, 1957-60. Report. Cmnd 939. London: HMSO, 1960.

2a Review Body on Doctors' and Dentists' Remuneration. Tenth Report. Cmnd 7903. London: HMSO, 1980.

${ }^{3}$ Review Body on Doctors' and Dentists' Remuneration. Eleventh report. Cmnd 8239. London: HMSO, 1981.

4 Anonymous. Prime Minister's statement. Br Med 7 1981 ;282:1722.

${ }^{5}$ Hall C. College nurses attack TUC health union over pay talks. Guardian 1982 April 29:3.

6 Anonymous. A fresh start. $B r \operatorname{Med} \mathcal{f} 1966$;i:1183-5.

${ }^{7}$ Anonymous. Log jam breaks. Br Med $\mathcal{F} 1976 ; \mathrm{i}: 60$. 